\title{
Executing Strategy with the Balanced Scorecard
}

\author{
Michael L. Werner (Corresponding author) \\ School of Business Administration, University of Miami \\ 5250 University Drive, Coral Gables, Florida 33146, United States of America \\ Business School, University of Shanghai for Science and Technology \\ Tel: +1-305-321-1139_Ｅ-mail: mwerner@miami.edu
}

Fuyuan Xu

Business School, University of Shanghai for Science and Technology

516 Jun Gong Road, Shanghai 200093, China

Tel: +86-21-5527-3540Ｅ-mail: xufy@usst.edu.cn

Received: June 29, 2011

Accepted: August 18, 2011 Published: January 5, 2012

doi:10.5430/ijfr.v3n1p88

URL: http://dx.doi.org/10.5430/ijfr.v3n1p88

\begin{abstract}
In order for organizations to succeed, it is important that managers establish clearly defined overall goals, core values, a vision of the future, and also develop a workable strategy to achieve these things. But simply having a good strategy in place does not guarantee that it will be successfully executed. The balanced scorecard, developed by Harvard professor Robert Kaplan and consultant David Norton, can help business leaders manage their businesses and help them achieve full execution of their strategies through the use of objectives, measures, targets, and initiatives. Instead of focusing solely on financial objectives, the balanced scorecard is an integrated set of performance measures organized around four distinct perspectives - financial, customer, internal, and innovation and learning. This paper explores business overall goals and mission, core values, vision, and strategy. Then the focus shifts to strategy execution through the use of the balanced scorecard.
\end{abstract}

Keywords: Balanced Scorecard, Strategy, Strategy Execution

\section{Mission - Overall Company Goals}

The overall goals of a firm define why the organization exists. Companies might be formed to earn money, to manufacture products, to provide services, or to improve the lives of those associated with the company. Most companies' goals are stated in general terms that are not easily quantified, which means that although progress toward fulfillment can be measured, it is not really possible to determine when the goals have been attained.

The goals of a business organization are usually a combination of nonfinancial and financial aspirations. Whether nonfinancial or financial, however, almost all goals have either a direct or indirect effect on the company's financial well-being. The next section explains why almost all goals can affect the financial health of a business.

Typically, nonfinancial goals do not mention money. Rather, they refer to activities that may or may not result in profits. A hospital's nonfinancial goals, for instance, might be to provide the best health care possible to its patients; to recruit and employ highly qualified workers; to provide a safe, pleasant environment for its employees and patients; and to create an atmosphere of caring for both the physical and the emotional concerns of its patients.

Note that the nonfinancial goals for the hospital are stated in very general language. More than specific results, these goals represent standards of conduct and performance toward which the hospital should always be striving. They are stated in such a way that it is very difficult, if not impossible, to determine when the goals have been attained.

For most business organizations, the primary financial goal is to earn a profit. What this really means, of course, is that the goal is to earn a return on investment for the business owner or owners. This goal may be worded as "achieving superior financial performance," "earning a reasonable return for the stockholders," "maximizing shareholder value," or similar language. As was the case with the nonfinancial goals, it is difficult to determine when these financial goals have been attained. 


\subsection{Goal Awareness}

Once goals have been set, the company should communicate them to every person in the organization. This communication improves the likelihood that a business will achieve its goals. Many companies use a mission statement - a summary of the main goals of the organization - to communicate the firm's goals to employees. The goals in a company's mission statement should address the concerns of all parties who have a stake in how the company conducts its business. For instance, Johnson \& Johnson's stakeholders include health care providers, consumers, suppliers, employees, the community, and stockholders. Johnson \& Johnson's mission statement communicates the firm's goals and presents the image of a responsible, ethical business.

\section{Core Values - What the Company Stands For}

Each of us has personal core values that define who we are, how we act, and what we stand for. These values define our perception of what is most important in life and also define a sense of right and wrong, of just or unjust. Companies must have a similar set of core values in order to succeed. Company values include a sense of caring and a commitment to the health and well being of people and the environment.

\section{Vision - The Hope for the Future}

Company leadership must develop a vision of the company's future. Where is the company going? What products and services will the company sell and how will it sell them? Where will the company conduct its business and how will the company learn, innovate, and grow as the future unfolds? These are all questions that are answered by vision.

\section{Strategy}

Once a company has established its mission, its core values, and its vision for the future, it must establish a workable strategy achieve them. It is not enough for a business to have a mission and vision that includes building wealth through corporate earnings, it must also have a strategy to create those earnings. For some companies, strategy includes low prices and high volume. For others the strategy is high quality, superior service, and higher prices. Some companies have a profit strategy based on fast inventory turnover, while others have an earnings strategy based on higher margins and slower turnover.

Putting together a successful business strategy involves analyzing the situation that exists and the situation that is anticipated which includes among other things, evaluating the company, competitors, and social, economic, and market conditions. A three step approach to establishing a strategy is to determine where you are today, where you would like to be in the future, and finally, how you are going to get there. The "how you are going to get there" is the business strategy. In forming a successful strategy, it is important to avoid focusing on the narrow view of business. For example, it is not wise to prepare a business strategy that focuses primarily on the financial aspirations of the company.

\subsection{Strategy Execution}

Typically the problem with strategy is not its creation but rather its implementation. According to Fortune Editor at Large, Patricia Sellers in her December 2008 article, Execution, Execution, Execution!, strategy execution has always been the number one reason why CEOs fail. Sellers states that this point has been preached by her colleague Geoff Colvin and management guru Ram Charan over the past decade. And this problem is not a new one. In a 1999 cover story on prominent CEO failures, Fortune estimates that in 70 percent of cases the problem was not a bad strategy, but rather failure to implement the strategy. Although having a good business strategy is critically important, it is safe to say that with strategy implementation failure rates of 70 percent to 90 percent, execution of strategy is even more critically important.

\subsection{Reasons for Failure to Execute Strategy}

There are several reasons why businesses fail to execute strategy. First, strategy is generally established by the firm's top management. Managers and employees at lower levels are far removed from the process of determining strategy so they are sometimes unaware of the strategy that top management has formulated. Lower level employees are not working to execute strategy because they do not even know what the strategy is. A second reason firms fail to execute strategy is, even if lower level employees are fully aware of the strategy, they may feel they are too low in the organization to really make a difference. These employees feel that the work they do is so minor and so far removed from the overall performance of the company that their actions will have very little or no impact on whether the company adequately executes its strategy. Third, even if employees are aware of the strategy and they feel their actions could contribute to strategy execution, employees may not know what to do to. In this case, the employees know the strategy, they feel that they can make a difference, but they do not know what to do. Fourth, even if employees are aware of the strategy and know exactly what to do to execute the strategy, they may not act so that the strategy is successfully executed. In this 
situation, the employees may be in full favor of helping to execute the strategy, but their commitment to the deluge of work necessary to take care of the daily routine of established procedures and business details, they do not carve out time to do what it takes to execute the strategy. They are so busy tending to activities based on their own perception of what they should be doing to deal with daily routine details, they do not take time to stop, think, and act to implement strategy. It is like a team of painters so busy painting the front of a building, they do not take time to notice that the other end of the building is on fire and burning down and other activities (helping to put out the fire) are actually more beneficial.

The questions then become: How can we put together a winning strategy that covers all the necessary aspects of our business and how can we insure that the strategy is successfully executed? The answers to these questions are not easy and in the remainder of this paper we explore how the balanced scorecard can help with strategy development and implementation.

\section{The Balanced Scorecard}

In the past, business in the United States has focused almost exclusively on financial amounts to measure success. Success has been gauged by how much revenue can be generated, how much costs can be reduced, or how much profit can be earned. To stay viable in today's competitive environment, however, companies must begin to also consider nonfinancial performance measures in evaluating business performance.

Developed by Harvard professor Robert Kaplan and consultant David Norton, the balanced scorecard does not focus solely on financial objectives of the firm. Rather the scorecard shifts the focus from financial objectives to include other important areas of concern.

\subsection{Balanced Scorecard Perspectives}

The balanced scorecard is an integrated set of performance measures organized around four distinct perspectives financial, customer, internal, and innovation and learning. (See Figure 1).

\subsubsection{Financial Perspective}

The financial perspective focuses on the financial success of the company. The financial perspective of business has been the focus of attention for decades. The yardstick by which success is judged is earnings, earnings per share, earnings growth, and return on investment measures. Unfortunately, focusing primarily on financial measures causes management to make poor decisions. For example, it might seem prudent for a company to terminate employees to reduce costs and improve net income, but by doing so the company casts off the tremendous value the employees bring to the firm. What is more, the terminated employees and all their knowledge and abilities will likely be hired and used by competing companies that gain the benefit of their years of experience and training, virtually free of charge. True, terminating employees reduces cost without negatively impacting the corporate balance sheet, but the employees are valuable off-balance sheet assets that are discarded and are available to other companies and are most often re-hired in the same industry. As time passes, the company that terminated the employees will suffer through various problems associated with losing the depth of knowledge and history the company once had when these workers were still in its employ. The message here is not that employees should be kept when it is truly desirable to terminate them, but instead that companies should consider all aspects of the termination decision instead of focusing almost exclusively on the financial perspective.

\subsubsection{Customer Perspective}

The customer perspective focuses on how the company is perceived by its customers relative to how the company would like to be perceived by its customers. Accordingly, companies must determine how they would like the company to appear to their customers. However, simply because a company knows how it would like to appear to its customers does not automatically make it happen. Often, the way a company would like to appear to its customers does not resemble the way the company actually does appear to its customers. To maintain their viability companies must focus on the customer perspective of their businesses.

\subsubsection{Internal Perspective}

The internal perspective relates to the ability of business processes within the business to get the job done. "The job" is anything that the business needs to accomplish. For a Dow Chemical production facility the job might be producing high quality products in an efficient manner. For a retail location of Tiffany \& Company the job is selling exceptionally high quality jewelry to upscale customers. To sell the jewelry, Tiffany will need certain resources in place. For example, it will need exceptionally high quality stores in affluent shopping areas, with high quality store furnishings and lighting to showcase their products. Additionally, Tiffany will need computers, software systems, and other processes to make and 
record sales transactions. For a university, the job is teaching students, or at least one of "the jobs" is teaching students. To do this, the university could function with crude, uncomfortable classrooms, but they could get the job done in a better fashion if they had modern classrooms with climate control, comfortable seating, adequate white-boards, computer projections systems, online capabilities, and the like. Learning would also be enhanced if students had access to computer based resources and communications capabilities. As universities make improvements to the teaching and learning environment, they are making improvements to the internal perspective.

\subsubsection{Innovation, Learning, and Growth Perspective}

The innovation, learning, and growth perspective is probably the most important of the four perspectives. This perspective is concerned with the organization maintaining a ready posture for the future. In many discussions of this perspective the focus largely relates to employees and employee capabilities. The thought is that the financial perspective is for the benefit of investors and business owners, the customer perspective is for, of courses, for the benefit of customers, the internal perspective is for the benefit of the company itself, and so the innovation, learning, and growth perspective must be for the one remaining constituency, the employees. In large part the innovation, learning, and growth perspective truly is for the benefit, so to speak, of employees - but is it also much more than that. This perspective focuses on all aspects of preparing the company for whatever the future holds including keeping up with technical trends and product innovation, developments in new and lower cost product sourcing, competitive pressures for changes including product, marketing, and product delivery innovation, and much more. In recent years some top US companies such as Polaroid, that had superior name-brand-recognition and financial strength failed to adequately focus on innovation, learning, and growth which caused a tremendous downturn in the company's businesses.

The biggest challenge facing business today is not being successful this minute, but rather being successful as the future unfolds. This is why the innovation, learning and growth perspective is so critically important.

To implement the balanced scorecard, managers must develop objectives, measures, targets, and initiatives for each perspective.

\subsection{Objectives}

Objectives are concise statements that articulate what the organization hopes to accomplish. Objectives should be established for each of the perspectives of the balanced scorecard. Objectives are goals associated with perspectives and each objective should further the company's strategy. If an objective does not support a firm's business strategy, it should be eliminated, or, the strategy should be changed so that it embraces the objective. This simple but important concept is critical and in many cases has led companies to reexamine their entire approach to establishing strategy. Table 1 depicts the overall objective for each of the balanced scorecard perspectives.

Once the strategy is established and objectives set, will that balanced, winning strategy along with reasonable objectives for each perspective result in appropriate employee behavior? In other words, will employees act to execute the strategy? It is quite likely that the answer to this question is no. Even if employees fully understand the company's strategy and the various balanced scorecard objectives, they well probably not behave in a way that achieves execution of the strategy. To execute the strategy, three additional important elements of the balanced scorecard must be established - measures, targets, and strategic initiatives.

\subsection{Measures}

\section{"If you can't measure it, you can't manage it."}

\section{Peter Drucker}

According to Peter Drucker, measuring business activity is keenly important. It is safe to say that Drucker felt that if you want something to happen in business, you must measure it. For example, if you desire to reduce the number of defective units produced by each employee, measure it. When employees realize that their performance is being measured and monitored, improvements will occur.

Measures are descriptions of how success in achieving objectives will be gauged. Measures help managers quantify the extent to which the balanced scorecard objectives have been met. It is not enough to establish an objective without also establishing a means to measure the degree to which the objective has been achieved. Accordingly, the company should establish measures to gauge the success of each of its objectives. Once measures have been established, performance targets further encourage employees to act to fully execute strategy.

\subsection{Targets}

Targets specify the level of performance or rate of improvement desired for each measure. The idea is that establishing 
measures without also informing employees of management's expectations will not result in performance that meets those expectations. Employees should be aware of not only the measure employed, but also the target to aim for to achieve success. Table 2 depicts examples of measures and targets that might be used to employ the balanced scorecard.

\subsection{Initiatives}

Initiatives are short-term programs and actions that will help achieve the established targets. For example, if one of the company's objectives is to have a well trained workforce, it will be necessary to establish a training program if one does not already exits. Table 3 presents examples of balanced scorecard initiatives

How does the balanced scorecard bring perspectives, strategy, objectives, measures, targets, and initiatives together? As complicated as it seems, managers can find their way through the process of implementing the balanced scorecard to execute strategy. To do this, managers follow a map - in this case, a strategy map.

\subsection{Strategy Maps}

Companies use strategy maps to bring the elements of the balanced scorecard together in a meaningful way. Strategy maps are useful for implementing the balanced scorecard and for insuring that the scorecard works to help the company to execute strategy.

Strategy maps are read from the bottom up. That is, there is a notion that the learning, innovation and growth should be addressed first, then internal business processes next, which leads into a focus on customer concerns, and finally the result of bringing everything together should be good financial results. Table 4 presents the general format for strategy maps.

\section{Formulating Strategy - The Impact of the Balanced Scorecard}

In some cases, business leaders have attempted to create winning business strategies only to find they have left out an important area of concern. Or in more extreme cases, business executives have formulated strategies that are so narrowly focused the implementation of their strategy actually works to the company's detriment instead of its benefit.

The notion that each objective of the balanced scorecard must support the company's business strategy has helped business leaders create strategies that address all of the important aspects of their businesses. This is because as managers attempt to create objectives that are tied to strategy, they sometimes learn that their business strategy is lacking. Weaknesses in the strategy are detected when it becomes impossible to create strategy-tied objectives for one or more of the perspectives. Strategy weaknesses may also be detected when an important objective is created but it is unassociated with the strategy. In these cases, the strategy should be expanded to include the new areas of concern. What this means is that as managers establish worthy objectives, if some objectives cannot be tied to an element of strategy the exercise may be revealing that the strategy is incomplete. This is not always the case, however, in that some of the objectives that do not tie back to strategy may fail to support the mission, values, or vision for the company, which is an indication that those objectives should be eliminated. Through the use of the balanced scorecard, managers create objectives that support strategy and also create a strategy that is broad enough to address each of the balanced scorecard perspectives.

\section{Conclusion}

The balanced scorecard helps enterprise leaders manage their operations and helps them execute their strategy. Strategy maps help inform employees of the company's strategy and objectives. However, even if employees are aware of the company's strategy and its objectives, they will generally do little to achieve strategy execution. This is due to various reasons including the idea that employees are so involved doing the routine things they think are important that they do not take actions that result in strategy execution; in part because they may not even know the actions they can take to execute strategy.

The point at which managers and employees are finally inspired to act to execute strategy happens when measures and targets are established. Measures and targets provide gauges of success for specific business activities. When the balanced scorecard is adopted, employees become aware that their performance will be judged based on these measures and targets. Accordingly, employees will act to achieve the established performance targets. Strategy execution occurs because the measures and targets are tied to achieving objectives and the objectives are tied to the strategy. It is critically important to achieve strategy execution because strategy is the company's means of realizing its mission, values, and vision. 


\section{References}

Charan, R. \& Colvin, G. (1999). Why CEOs Fail, Fortune, [Online] Available: http://money.cnn.com/magazines/fortune/fortune_archive/1999/06/21/261696/index.htm

Kaplan, R. S. \& Norton, D. P. (1996). The Balanced Scorecard - Translating Strategy Into Action, HBS Press

Niven, P. R., (2002). Balanced Scorecard Step by Step - Maximizing Performance and Maintaining Results, Wiley

Sellers, P. (2008). Execution, Execution, Executions!, Fortune Postcards, [Online] Available: http://postcards.blogs.fortune.cnn.com/2008/12/18/execution-execution-execution/

Table 1. Overall balanced score objectives

\begin{tabular}{|l|l|}
\hline \multicolumn{1}{|c|}{ Perspective } & \multicolumn{1}{c|}{ Overall Objective } \\
\hline Financial Perspective & To succeed financially \\
\hline Customer Perspective & $\begin{array}{l}\text { To achieve our vision of how the company should } \\
\text { appear to customers }\end{array}$ \\
\hline Internal Perspective & $\begin{array}{l}\text { To excel at having superior business processes to } \\
\text { satisfy shareholders and customers }\end{array}$ \\
\hline Innovation, and Learning Perspective & To sustain the ability to change and improve \\
\hline
\end{tabular}

Table 2. Examples of balanced score targets

\begin{tabular}{|c|c|c|}
\hline Perspective & & Examples of Targets \\
\hline Financial Perspective & $\begin{array}{l}\text { - Return on investment } \\
\text { - Profitability } \\
\text { - Revenue growth } \\
\text { - Revenue mix } \\
\text { - Cost reduction }\end{array}$ & $\begin{array}{l}\text { - Return on investment of } 15 \% \\
\text { - } 5 \% \text { increase in operating income } \\
\text { - } 20 \% \text { growth in sales revenue } \\
\text { - } 30 \% \text { of revenue from wholesale } \\
\text { customers } \\
\text { - } 3 \% \text { decrease in administrative cost }\end{array}$ \\
\hline Customer Perspective & $\begin{array}{l}\text { - Market share } \\
\text { - Customer acquisition } \\
\text { - Customer retention } \\
\text { - Customer profitability } \\
\text { - Customer satisfaction }\end{array}$ & $\begin{array}{l}\text { - } 30 \% \text { market share } \\
\text { - } 1,000 \text { new customer acquisitions per } \\
\text { month } \\
\text { - Repeat customer rate of } 50 \% \\
\text { - Average customer profit of } \$ 1,000 \\
\text { - Customer satisfaction rating of } 4.9 \text { on a } 5 \\
\text { point scale }\end{array}$ \\
\hline Internal Perspective & $\begin{array}{l}\text { - Process quality measures } \\
\text { - Time to process an order } \\
\text { - Number of computers } \\
\text { - Lead-times } \\
\text { - Amount of scrap }\end{array}$ & $\begin{array}{l}\text { - Zero defects } \\
\text { - Reduce time to process an order to } 3 \\
\text { minutes } \\
\text { - Increase the number of computers by } \\
30 \% \\
\text { - Lead time reduced by } 80 \% \\
\text { - Amount of non recycled scrap reduced } \\
\text { by } 90 \%\end{array}$ \\
\hline $\begin{array}{l}\text { Innovation, and } \\
\text { Learning Perspective }\end{array}$ & $\begin{array}{l}\text { - Amount spent on research } \\
\text { - Number of training } \\
\text { programs } \\
\text { - Employees trained } \\
\text { - Employee retention } \\
\text { - Employee productivity } \\
\text { - Number of new products }\end{array}$ & $\begin{array}{l}\text { - Amount spent on research of } \$ 100,000 \\
\text { - } 5 \text { training programs per month } \\
\text { - Each employees attends one training } \\
\text { program per month } \\
\text { - Employee retention increased by } 20 \% \\
\text { - Employee productivity of } 18 \text { transactions } \\
\text { per day } \\
\text { - Number of new products increased by } \\
20 \%\end{array}$ \\
\hline
\end{tabular}


Table 3. Balanced score initiatives

\begin{tabular}{|l|l|}
\hline \multicolumn{1}{|c|}{ Perspective } & \multicolumn{1}{c|}{ Examples of Initiatives } \\
\hline Financial Perspective & $\begin{array}{l}\text { Establish a program for comparing selling } \\
\text { prices to those of competitors }\end{array}$ \\
\hline Customer Perspective & $\begin{array}{l}\text { Establishing a customer feedback and survey } \\
\text { system }\end{array}$ \\
\hline Internal Perspective & Establishing a new maintenance program \\
\hline Innovation, and Learning Perspective & $\begin{array}{l}\text { Establishing an employee training program } \\
\text { Requiring attendance at appropriate trade shows }\end{array}$ \\
\hline
\end{tabular}

Table 4. Sample Strategy Map

\begin{tabular}{|c|c|c|c|}
\hline \multicolumn{4}{|c|}{ Sample Balanced Scorecard Strategy Map } \\
\hline Perspective & Objectives & Measures & Targets \\
\hline \multirow{3}{*}{ Financial } & \multirow[t]{3}{*}{ To succeed financially } & Measure A & Target $\mathrm{A}$ \\
\hline & & Measure B & Target B \\
\hline & & Measure C & Target C \\
\hline & 4 & & \\
\hline \multirow[t]{4}{*}{ Customer } & \multirow{4}{*}{$\begin{array}{l}\text { To achieve our vision of how the company } \\
\text { should appear to customers. Customers are } \\
\text { impressed with the company and its } \\
\text { employees, its products, and its services }\end{array}$} & \multirow{4}{*}{$\begin{array}{l}\text { Measure D } \\
\text { Measure E } \\
\text { Measure F }\end{array}$} & Target D \\
\hline & & & Target $\mathrm{E}$ \\
\hline & & & Target $\mathrm{F}$ \\
\hline & & & \\
\hline & & & \\
\hline \multirow[t]{3}{*}{ Internal } & \multirow{3}{*}{$\begin{array}{l}\text { To excel at having superior business } \\
\text { processes to satisfy shareholders and } \\
\text { customers }\end{array}$} & \multirow{3}{*}{$\begin{array}{l}\text { Measure G } \\
\text { Measure H } \\
\text { Measure I }\end{array}$} & \multirow{3}{*}{$\begin{array}{l}\text { Target } \mathrm{G} \\
\text { Target } \mathrm{H} \\
\text { Target I }\end{array}$} \\
\hline & & & \\
\hline & & & \\
\hline $\mathbf{A}$ & $\mathbf{C}$ & & \\
\hline \multirow{4}{*}{$\begin{array}{l}\text { Learning and } \\
\text { Growth }\end{array}$} & \multirow{4}{*}{$\begin{array}{l}\text { To sustain the ability to change and } \\
\text { improve. To have a trained and productive } \\
\text { workforce. To create innovative } \\
\text { products and services. To strive for best } \\
\text { product and service sourcing. }\end{array}$} & Measure J & \multirow{4}{*}{$\begin{array}{l}\text { Target J } \\
\text { Target K } \\
\text { Target L }\end{array}$} \\
\hline & & Measure K & \\
\hline & & Measure L & \\
\hline & & & \\
\hline
\end{tabular}

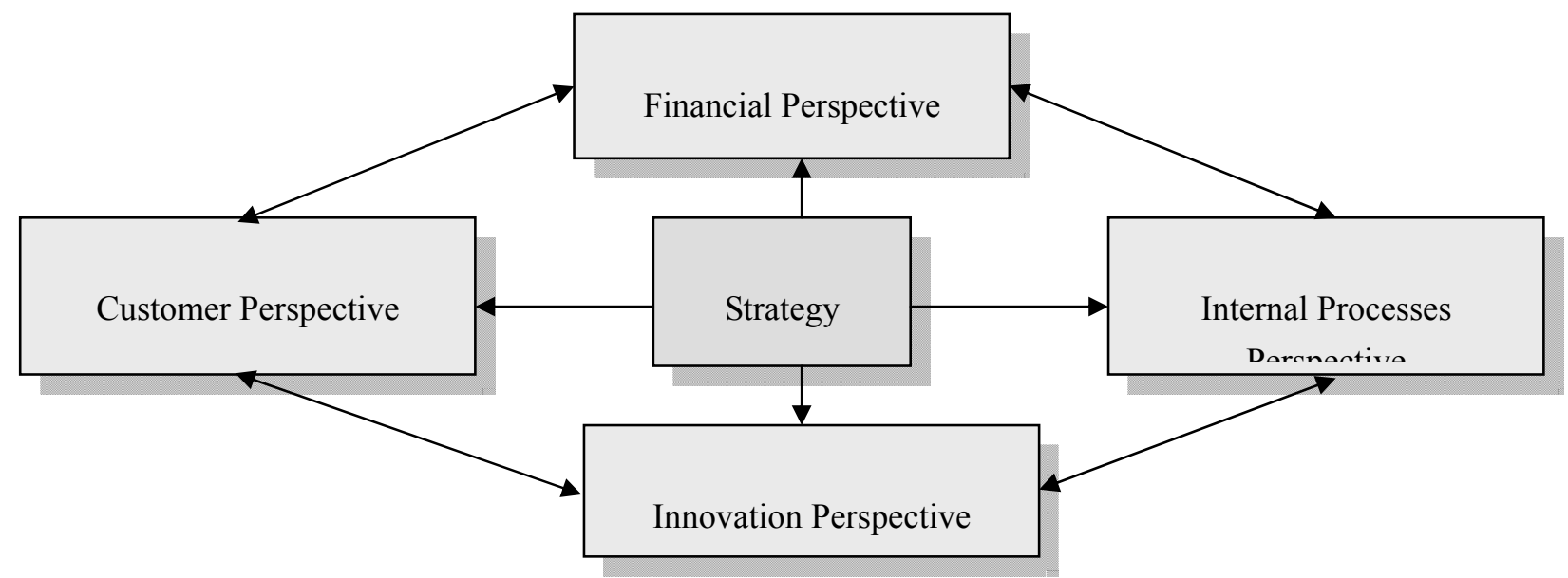

Figure 1. Four Balanced Scorecard Perspectives 